\title{
EFFECT OF ADDING PENICILLIUM ROQUEFORTI SPORES AND ALPHA TOCOPHEROL ON LEAD TOXICITY IN CULTURED NILE TILAPIA (OREOCHROMIS NILOTICUS)
}

\author{
BARAKAT, M. $^{1}$; EL-GOHARY, M.S. ${ }^{2}$ and AMANY, M. DIAB ${ }^{3}$ \\ ${ }^{1}$ Biochemistry Unit, Animal Health Research Institute- Kafr El-Sheikh, Branch. \\ ${ }^{2}$ Fish Diseases Unit, Animal Health Research Institute- Kafr El-Sheikh, Branch \\ ${ }^{3}$ Aquatic Microbiology Faculty of Aquatic and Fisheries Sciences - Kafr El-Sheikh University.
}

Received: 12 February 2017; Accepted: 22 March 2017

\begin{abstract}
This study was designed to investigate, evaluate and compare the detoxifying efficiency of Penicillium roqueforti spores and Alpha-Tocopherol dietary supplementation in case of sublethal exposure of Nile tilapia (Oreochromis niloticus) to Lead. A total of 100 fish $O$. niloticus were divided into five equal groups. Group one, untreated control free aquarium water, was fed on basal diet lead acetate (ninety $\mathrm{mg} / \mathrm{L}$ ) was added to the aquarium water to the other four groups. Group (2), lead acetate control positive fed on basal diet, group (3) fed on diet supplemented with $\left(9 \times 10^{2} \mathrm{CFU} / \mathrm{kg}\right.$ feed) of Penicillium roqueforti, group (4) fed on diet supplemented with Alpha-Tocopherol (300mg/kg feed), group (5) fed on diet supplemented with Penicillium roqueforti spores in addition to Alpha-Tocopherol as $\left(9 \times 10^{2} \mathrm{CFU} / \mathrm{kg}\right.$ feed and $300 \mathrm{mg} / \mathrm{kg}$ feed) respectively. Nile tilapia fed at $3 \%$ body weight per day for 10 weeks. Results of $\mathrm{Pb}$ intoxicated control positive group showed no characteristic clinical signs with presence of some postmortem and histopathological changes. Moreover serum analysis showed significant decreasing in growth hormone $(\mathrm{GH})$, Calcium $(\mathrm{Ca})$, phosphorus, Serum bactericidal activity and Serum lysozyme activity with increasing the mortality rates after challenging with Aeromonas hydrophila. Lead residues in blood, musculatures, gills, kidney and liver indicated that lowest Lead residue was recorded in musculatures but the highest residues were recorded in gills in all groups. Supplementation of Penicillium roqueforti spores and Alpha-Tocopherol improves the adverse effect of Lead in $3^{\text {rd }}, 4^{\text {th }}$ and $5^{\text {th }}$ groups. Best detoxification results were in $5^{\text {th }}$ group. It could be concluded that inclusions of $9 \times 10^{2} \mathrm{CFU} / \mathrm{kg}$ feed Penicillium roqueforti spores in addition to $300 \mathrm{mg} / \mathrm{kg}$ feed Alpha-Tocopherol in O.niloticus diets could reduce Lead adverse effects to the favor of fish health, immunity and minimizing the $\mathrm{Pb}$ residues specially in fish musculatures.
\end{abstract}

Keywords: Oreochromis niloticus, Lead acetate, Penicillium roqueforti, Alpha-Tocopherol.

\section{INTRODUCTION}

The heavy metals effects on environment and human health are of great interest, especially aquatic products (Uluozlu et al., 2007). Some of these metals, as $\mathrm{Cd}$ and $\mathrm{Pb}$, are toxic even at low concentrations to living organisms (Stephen et al., 2000). The effects of Lead on the environment is usually addressed and highlighted in respection to its effects on human, including loss of coordination, mental retardation and learning dysfunction (Olaifa et al., 2003).

Anthropogenic and natural sources release heavy metals into aquatic ecosystem continuously. In freshwaters heavy metals cause serious problem because their bioaccumulation, long persistence, biomagnifications in the food chain and their toxicity

Corresponding author: Dr. BARAKAT, M.

E-mail address: mmbarakat2003@gmail.com

Present address: Biochemistry Unit, Animal Health Research Institute- Kafr El-Sheikh, Branch to the living organisms. Fish, are considered as heavy metal pollution indicators. Lead is heavy metal which has been used in many ways including smelting, mining, refining, battery manufacturing, gasoline, electrical wiring, painting, making of stained glass and ceramic glazing. Lead has non-degradable nature so it gets into the environment moreover eventually enters the man and animal's blood stream. Lead is accumulated in soft tissues as brain, nervous system, liver and kidneys. In fishes, Lead accumulated in various tissues (Linde et al., 2004) causing alterations in hematological and biochemical parameters (Ates et al., 2008) and changing physiological, behavioral parameters and genetic. Fish is the most susceptible aquatic inhabitants to heavy metals pollution or contamination (Sidra and Sumera, 2012).

Heavy metals are chemical stressors and disease development will reflect the interactions between stressors, the host and the disease causing the situation. Moreover, Suppression of immune system and immune response may result from several pollutants including heavy metals which provide 
opportunities for many pathogens entering, but up-till now the heavy metals effects on the immune response and immune system are not fully understood (Storelli et al., 2002).

Recently microbial systems as fungi, algae and bacteria have been explored for their role in heavy metals removal from polluted environments. One form of this bioremediation is Mycoremediation where fungi are used to degrade or sequester environmental contaminants (Dugal and Gangawane, 2012). Fungi biomasses are known to be heavy metals tolerantes (Gavrilesca, 2004). Fungi offer the advantage of having cell wall material that shows excellent metal-binding properties (Gupta et al., 2000). Penicillium and Aspergillus isolates were the most heavy metals tolerants and exhibited strong growth, often exceeding the isolates grown in agar medium without heavy metals that after studying of thirty-six micro-organisms, of fungi and yeasts strains that were isolated from sites in Tangier, Morocco contaminated with heavy metal for screening the resistance of these fungi to heavy metals $(\mathrm{Cr}, \mathrm{Pb}, \mathrm{Zn}$ and $\mathrm{Cu}$ ) (Ezzouhri et al., 2009).

Alpha-Tocopherol has an important role in antioxidant activity and immune response enhancement; it gives the protection to the body cells from the adverse effects of free radicals that produced during several stressors and normal cell activity (John et al., 2001). Alpha-Tocopherol maintains the cell membrane structure integrity of the important immune cells causing enhancement of fish immunity as well as antioxidants activity (Montero et al., 2001;
Puangkaew et al., 2004). El-Shebly (2009) reported that Oreochromis niloticus had protected against $\mathrm{Pb}$ induced oxidative stress by vitamin $\mathrm{E}$.

The present work was conducted to investigate the adverse effects of single sub-lethal dose of Lead on Oreochromis niloticus and evaluate the best protective effect of Penicillium roqueforti spores and/or Alpha-Tocopherol dietary supplements in reduction Lead drastic effects.

\section{MATERIALS AND METHODS}

1. Fish and experimental design: A total number of 100 apparently healthy $O$. niloticus with average body weight of $50 \pm 10 \mathrm{~g} /$ fish were obtained from a private fish farm at Kafrelsheikh governorate transported alive to the laboratory of Animal health research institute at Kafrelsheikh and kept in glass aquaria. Fish were acclimated for one week; the health status was examined throughout the acclimation period. During the acclimation fish fed on the pelleted basic diet only contained $30 \%$ protein twice daily. The aquaria were supplied with chlorine free tap water according to Innes, (1966). The aquaria were aerated continuously by electric pump and held at $25 \pm 2^{\circ} \mathrm{C}$ and half of the water was changed daily with respect to constant Lead acetate concentration as $90 \mathrm{mg} / \mathrm{l}$ in Lead treated groups. Fish were randomly divided equally to five experimental groups. Penicillium roqueforti spores and Alph-Tocopherol dietary supplements were used and mixed thoroughly with the prepared basal fish diet during its preparation.

Table 1: Outline of the experimental design.

\begin{tabular}{cccc}
\hline Group & No & Lead acetate* & Diet \\
\hline 1 & 20 & $0.0 \mathrm{mg} / \mathrm{l}$ & Basal diet $* *$ \\
\hline 2 & 20 & $90 \mathrm{mg} / \mathrm{l}$ & Basal diet \\
\hline 3 & 20 & $90 \mathrm{mg} / \mathrm{l}$ & Basal diet $+\left(9 \times 10^{2} \mathrm{CFU} / \mathrm{kg}\right.$ feed $)$ of Penicillium roqueforti*** \\
\hline 4 & 20 & $90 \mathrm{mg} / \mathrm{l}$ & Basal diet $+(300 \mathrm{mg} / \mathrm{kg}$ feed $)$ of Alpha-Tocopherol $* * * *$ \\
\hline 5 & 20 & $90 \mathrm{mg} / \mathrm{l}$ & Basal diet $+\left(9 \times 10^{2} \mathrm{CFU} / \mathrm{kg}\right.$ feed $)$ of Penicillium roqueforti + \\
& & $(300 \mathrm{mg} / \mathrm{kg}$ feed $)$ of Alpha-Tocopherol \\
\hline
\end{tabular}

* Lead acetate: Delta Company, Egypt. **Basal diet (Tocopherol free)

***Penicillium roqueforti: Total Viable Count $9 \times 10^{2}$ CFU. Kindly Provided by Prof. Dr. Riad Khalil, Department of Fish and Avian, Faculity of Vet., Med., Alex. Univ. **** Alpha-Tocopherol: BASF Company, Egypt, Batch no. 131076.

2. Clinical sings and postmortem lesions of fish: During the duration of experiment clinical signs and post mortem examination of Oreochromis niloticus were performed according to Austin and Austin (1987) and Plumb and Bowser (1982).

3. Blood collection: At end of the $4^{\text {th }}$ and the $8^{\text {th }}$ week of the experiment, $2 \mathrm{ml}$ blood sample from each fish from the caudal vessels were collected from 3 fish from each group according to (Hawak et al., 1965). One $\mathrm{ml}$ of blood was collected with syringe containing anticoagulant (Heparin) and used for detection of Lead in blood by atomic absorption spectrophotometric method according to (Jonsson et al., 2012) while other blood samples used for serum collection (Lied et al., 1975). Determination of 
growth hormone was done according to (Kates and Albericio, 2000) and (Nakane and Kawaoi, 1974). Determination of phosphorus was determined by the colorimetric method according to (APHA, 1976) and calcium was determined by atomic absorption spectrophotometer according to (AOAC, 1984). Serum bactericidal activity was detected according to (Rainger and Rowley, 1993). Serum lysozyme activity was measured with the turbidimetric method described by Engstad et al. (1992). The result was expressed as one unit of lysozyme activity was defined as a reduction in absorbency of $0.001 / \mathrm{min}$.

4. Detection of Lead residues in Muscular tissues, gills, kidney and liver: At the $4^{\text {th }}$ and $8^{\text {th }}$ weeks of the experiment dorsolateral musculature, gills, kidney and liver were rapidly removed from the fish and were stored in plastic container at $-20^{\circ} \mathrm{C}$ for Lead residues analysis. Samples prepared as a wet digestion procedure (Mason, 1991), then Atomic absorption spectrophotometric method was used for the determination of Lead as described in Perkin Elmer catalogue of atomic absorption model 2380, U.S.A (1982).

5. Challenge test: At the $9^{\text {th }}$ week ten fish from each group were bacteriologically examined and determined to be free from bacterial infection, then they were $\mathrm{I} / \mathrm{p}$ injected with $0.2 \mathrm{ml} /$ fish of culture suspension of pathogenic Aeromonas hydrophila previously adjusted to $10^{5}$. Specificity of death was determined by re-isolation of injected bacteria from freshly dead fish during the period of observation (one week) according to Soliman (1988).

6. Histopathological examination: At the end of the experiment specimens from different parts of liver, kidneys and gills were immediately fixed in $10 \%$ neutral buffered formalin, dehydrated cleared and then stained according to Bancroft et al. (2013).

7. Statistical analysis: The data were statistically analyzed by one way Anova test by S.P.S.S, (1997) program.

\section{RESULTS}

Clinically the experimentally Lead intoxicated Oreochromis niloticus ( $2^{\text {nd }}$ group) showed, no characteristic clinical signs externally comparing to the control negative (Lead free) group. Postmortem examination revealed the presence of edematous fluid, yellowish enlarged liver, enlarged gall bladder, congested spleen, kidneys and gills comparing to control negative group (Photo:1 A, B). Regarding to $3^{\text {rd }}, 4^{\text {th }}, 5^{\text {th }}$ groups externally were apparently healthy but Postmortem examination revealed to relatively enlarge pale liver, enlarged gall bladder and spleen comparing to the control negative group.

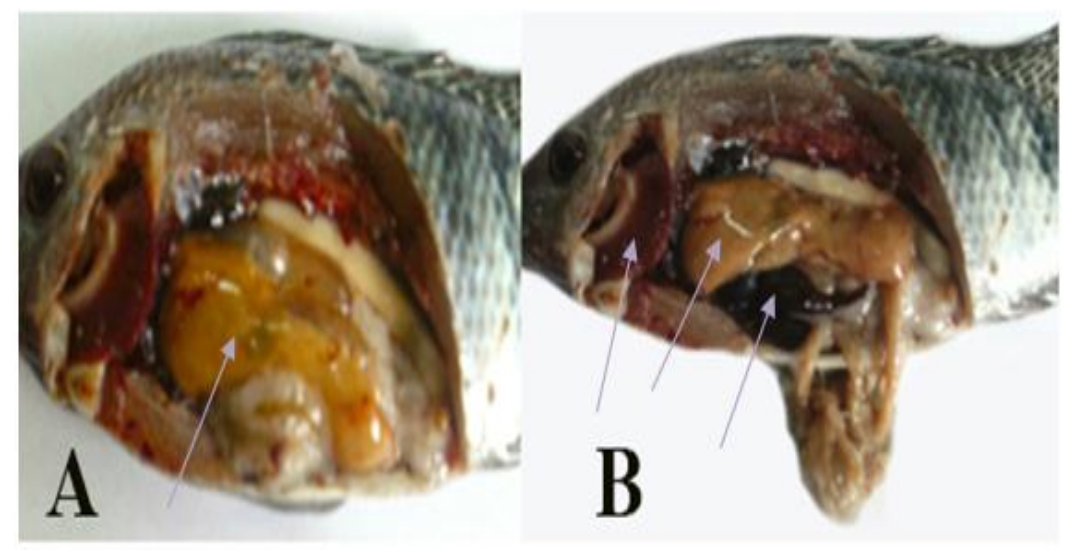

Photo (1): A- Experimentally Lead intoxicated O. niloticus shows, presence of edematous fluid and yellowish enlarged liver.

B- Experimentally Lead intoxicated $O$. niloticus shows, yellowish enlarged liver and enlarged congested spleen, kidney and gills.

The analysis of growth hormone, calcium and phosphorus levels in $2^{\text {nd }}$ group (control positive) showed significant reduction comparing to other groups moreover this reduction increased by increasing the period of exposure to Lead ( $8^{\text {th }}$ weeks). Highest levels of calcium and phosphorus levels were in control negative (untreated) group followed by $5^{\text {th }}$ group followed by $3^{\text {th }}$ group then $4^{\text {rd }}$ group respectively but best results of growth hormone levels were in $5^{\text {th }}$ group followed by $3^{\text {th }}$ group followed by $4^{\text {rd }}$ group then control negative (untreated) group respectively (Table 2) and Fig. (1, 2 and 3). 
Table 2: Effect of different treatments on growth hormone, calcium and phosphorus levels of (Oreochromis niloticus) during experimental period $(\mathrm{n}=3)$.

\begin{tabular}{|c|c|c|c|c|c|}
\hline & Groups & $\mathbf{N}$ & Growth Hormone (ng/mL) & Calcium (mg/L) & Phosphorus (mg/L) \\
\hline \multirow{3}{*}{$\frac{\mathscr{D}}{\mathbb{D}}$} & G1 & 3 & $6.59 \pm 0.17 \mathrm{c}$ & $3.03+0.04$ a & $2.23+0.04$ a \\
\hline & G2 & 3 & $2.5 \pm 0.21 \mathrm{~d}$ & $1.61+0.06 \mathrm{e}$ & $1.49+0.01 e$ \\
\hline & G3 & 3 & $14.53 \pm 0.29$ a & $2.14+0.03$ c & $1.85+0.03 \mathrm{c}$ \\
\hline \multirow[t]{2}{*}{$\ddot{z}$} & G4 & 3 & $8.12 \pm 0.07 b$ & $1.86+0.03 \mathrm{~d}$ & $1.55+0.02 d$ \\
\hline & G5 & 3 & $14.61 \pm 0.31 a$ & $2.83+0.03$ b & $2.19+0.01 b$ \\
\hline \multirow{5}{*}{ 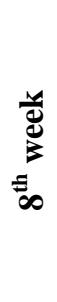 } & G1 & 3 & $7.99+0.05 b$ & $3.45+0.07$ a & $2.55+0.06 \mathrm{a}$ \\
\hline & G2 & 3 & $1.69+0.022 d$ & $0.67+0.03$ e & $0.76+0.03$ e \\
\hline & G3 & 3 & $9.66+0.23 \mathrm{a}$ & $1.25+0.03 \mathrm{~d}$ & $1.05+0.02 d$ \\
\hline & G4 & 3 & $6.42+0.23 \mathrm{c}$ & $1.71+0.03 \mathrm{c}$ & $1.35+0.01 \mathrm{c}$ \\
\hline & G5 & 3 & $10.02+0.05$ a & $2.58+0.1 \mathrm{~b}$ & $2.06+0.02 b$ \\
\hline
\end{tabular}

Means with different small litters in the same column at the same period are significantly different at $(\mathrm{p} \leq 0.05)$.

Examination of Lead residues in blood, gills tissues, liver, kidney and Musculatures indicated that significant increasing in $2^{\text {nd }}$ group (control positive) in comparing to other groups and the control negative group. Best results were in control negative group followed by group 5th then $4^{\text {th }}$ group then $3^{\text {rd }}$ group (Table 3 ) and Fig. (4, 5, 6, 7 and 8). Lowest Lead residues were recorded in musculatures but the highest residues were recorded in gills in all groups.

Table 3: Effect of different treatments on Lead residues ( $\mu \mathrm{g} / \mathrm{g}$ ) wet weight) of the examined samples of blood, gills, liver, kidney and Muscular tissues of (Oreochromis niloticus) during experimental period $(\mathrm{n}=3)$.

\begin{tabular}{|c|c|c|c|c|c|c|c|}
\hline & Groups & $\mathbf{N}$ & Blood & Gills & Liver & Kidneys & Musculature \\
\hline \multirow{5}{*}{ 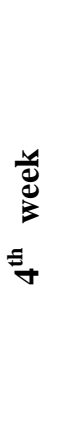 } & G1 & 3 & $0.614+0.01 \mathrm{e}$ & $0.74+0.03 \mathrm{e}$ & $0.021+0.001 \mathrm{e}$ & $0.53+0.02 \mathrm{e}$ & $0.003+0.001 \mathrm{e}$ \\
\hline & G2 & 3 & $6.27+0.14 \mathrm{a}$ & $7.43+0.08 \mathrm{a}$ & $3.16+0.03 \mathrm{a}$ & $6.27+0.02 \mathrm{a}$ & $1.35+0.27 a$ \\
\hline & G3 & 3 & $3.17+0.03 \mathrm{c}$ & $3.34+0.04 \mathrm{c}$ & $1.82+0.04 \mathrm{c}$ & $3.4+0.14 \mathrm{c}$ & $0.75+0.02 c$ \\
\hline & G4 & 3 & $3.82+0.07 \mathrm{~b}$ & $4.0+0.04$ b & $1.88+0.05 b$ & $3.5+0.07 \mathrm{~b}$ & $0.83+0.02 b$ \\
\hline & G5 & 3 & $2.01+0.01 d$ & $2.01+0.01 d$ & $1.71+0.01 d$ & $2.46+0.09 \mathrm{~d}$ & $0.56+0.04 d$ \\
\hline \multirow{5}{*}{$\begin{array}{l}\bar{d} \\
\vdots \\
\equiv\end{array}$} & G1 & 3 & $0.15+0.02$ e & $0.11+0.01 e$ & $0.01+0.001 \mathrm{e}$ & $0.002+0.001 \mathrm{e}$ & $0.001+0.001 \mathrm{e}$ \\
\hline & G2 & 3 & $6.99+0.02$ a & $7.6+0.31 \mathrm{a}$ & $3.96+0.07 a$ & $5.86+0.15$ a & $1.87+0.06$ a \\
\hline & G3 & 3 & $3.71+0.09$ b & $4.36+0.26 b$ & $2.38+0.03 \mathrm{~b}$ & $3.64+0.17 \mathrm{~b}$ & $0.85+0.03 b$ \\
\hline & G4 & 3 & $3.26+0.1 \mathrm{c}$ & $3.47+0.21 \mathrm{c}$ & $1.73+0.09 \mathrm{c}$ & $3.26+0.07 \mathrm{c}$ & $0.71+0.014 c$ \\
\hline & G5 & 3 & $1.3+0.14 d$ & $1.3+0.06 \mathrm{~d}$ & $0.55+0.04 d$ & $1.17+0.07$ d & $0.23+0.02 \mathrm{~d}$ \\
\hline
\end{tabular}

Means with different small litters in the same column at the same period are significantly different at $(\mathrm{p} \leq 0.05)$. 


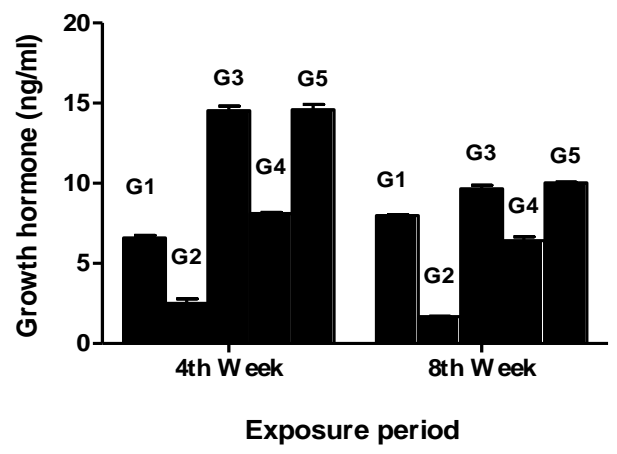

Fig. (1)

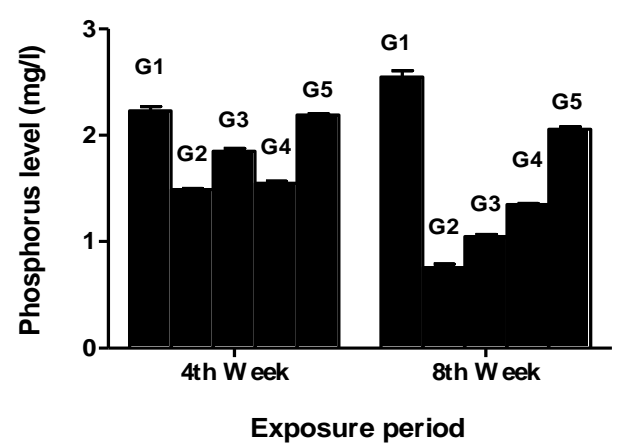

Fig. (3)

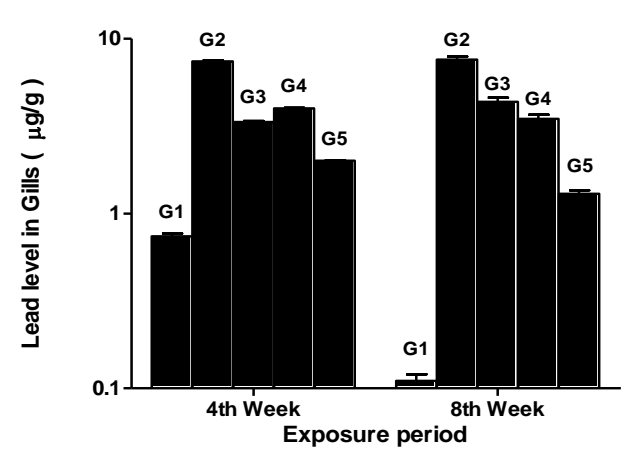

Fig. (5)

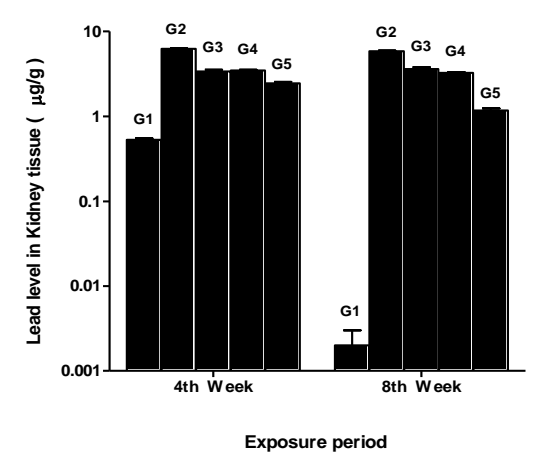

Fig. (7)

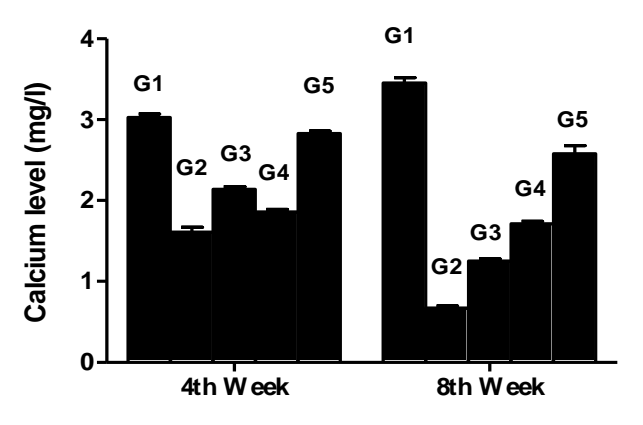

Exposure period

Fig. (2)

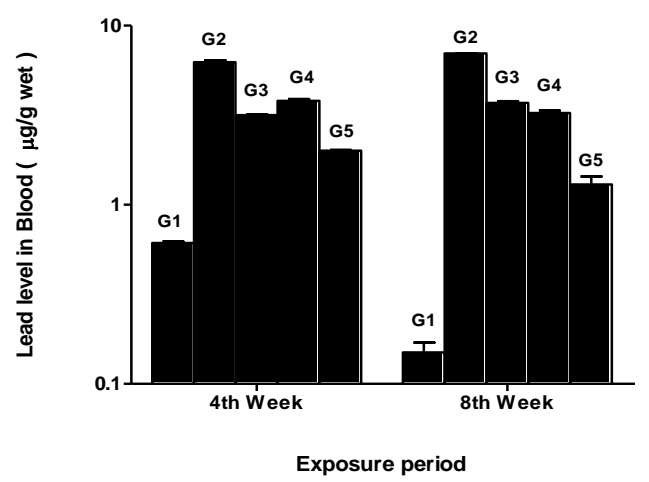

Fig. (4)

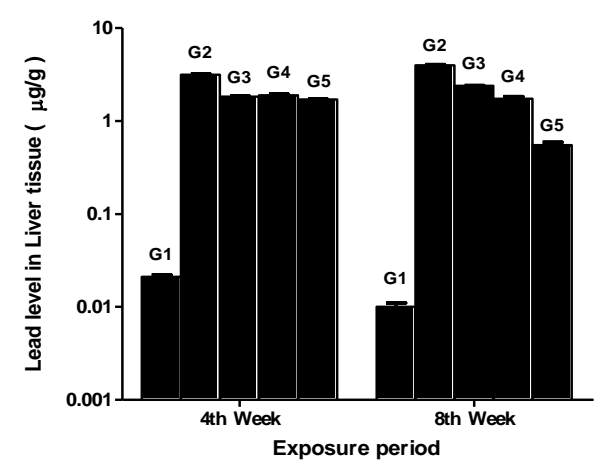

Fig. (6)

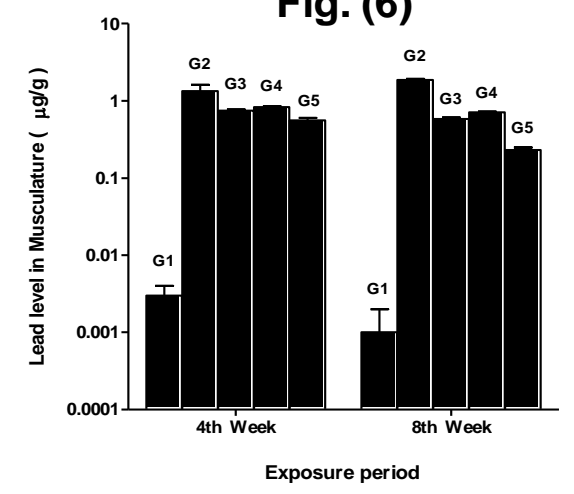

Fig. (8)

Concerning to the serum bactericidal activity as well as serum lysozyme activity significantly decreased in the lead-intoxicated control positive group ( $2^{\text {nd }}$ group) compared with control negative group especially with increasing the time of exposure to lead acetate at the $8^{\text {th }}$ week. Best detoxification results were in groups fed on diet contain $\left(9 \times 10^{2} \mathrm{CFU} / \mathrm{kg}\right.$ feed) of Penicillium Roquefort $+(300 \mathrm{mg} / \mathrm{kg}$ feed $)$ of Alpha-Tocopherol although the presence of $90 \mathrm{mg} / \mathrm{l} \mathrm{lead} \mathrm{acetate} \mathrm{(Table} \mathrm{4)} \mathrm{and} \mathrm{Fig.} \mathrm{(9} \mathrm{and} \mathrm{10).}$ 
Table 4: Effects of different treatments on serum lysozyme and bactericidal activity of (Oreochromis niloticus) during the experimental period $(n=3)$.

\begin{tabular}{|c|c|c|c|c|}
\hline & Groups & $\mathbf{N}$ & Lysozyme activity(units/ml) & Bactericidal activity survives index (SI) \\
\hline \multirow{3}{*}{ 节 } & G1 & 3 & $0.81+0.05 \mathrm{~d}$ & $4.67+0.05 \mathrm{c}$ \\
\hline & G2 & 3 & $0.48+0.01 \mathrm{e}$ & $3.71+0.13 \mathrm{~d}$ \\
\hline & G3 & 3 & $2.34+0.09 \mathrm{~b}$ & $6.27+0.02 \mathrm{~b}$ \\
\hline \multirow[t]{3}{*}{ Ё } & G4 & 3 & $1.37+0.04 \mathrm{c}$ & $5.25+0.04 \mathrm{c}$ \\
\hline & G5 & 3 & $3.27+0.02 \mathrm{a}$ & $7.42+0.02$ a \\
\hline & G1 & 3 & $0.95+0.01 \mathrm{~d}$ & $5.09+0.01 \mathrm{~b}$ \\
\hline \multirow{4}{*}{ 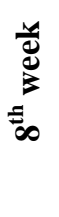 } & G2 & 3 & $0.32+0.01 \mathrm{e}$ & $2.28+0.03 \mathrm{~d}$ \\
\hline & G3 & 3 & $2.16+0.03 \mathrm{~b}$ & $5.18+0.02 \mathrm{~b}$ \\
\hline & G4 & 3 & $1.88+0.02 \mathrm{c}$ & $4.31+0.05 c$ \\
\hline & G5 & 3 & $2.55+0.08 \mathrm{a}$ & $6.15+0.02 a$ \\
\hline
\end{tabular}

Means with different small letters in the same column at the same period are significantly different at $(\mathrm{p} \leq 0.05)$.

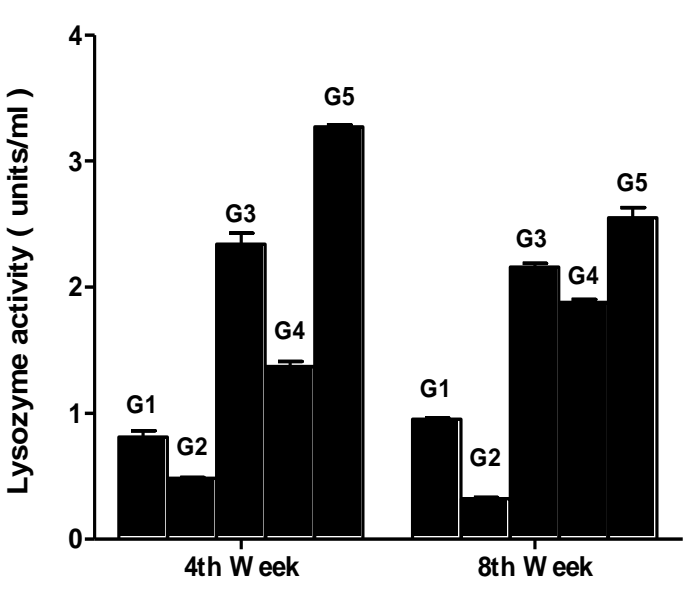

Exposure period

Fig. (9)

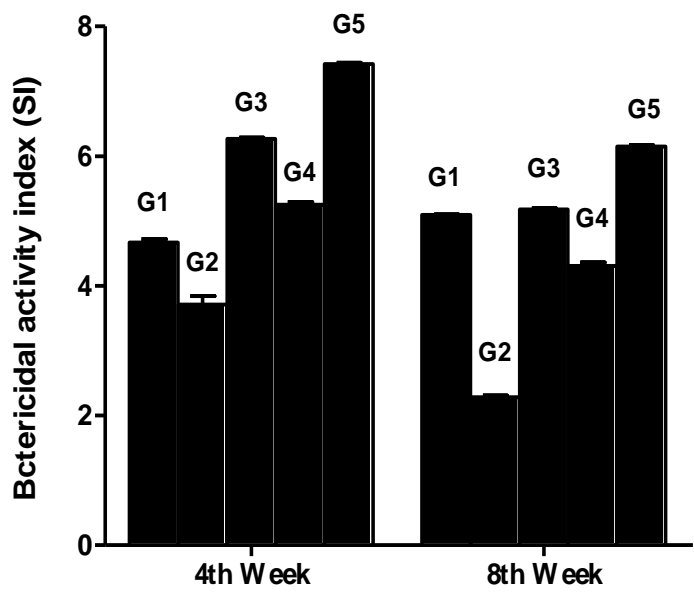

Exposure period

Fig. (10)

Mortalities of Lead acetate intoxicated Oreochromis niloticus challenged with Aeromonas hydrophila were significantly higher in control positive group than all treated groups and the control negative group (Table 5).

Table 5: Effects of different treatments on mortality percent of Oreochromis niloticus after challenge with Aeromonas hydrophila $(\mathrm{n}=10)$.

\begin{tabular}{cccccc}
\hline \multirow{2}{*}{ Group } & \multirow{2}{*}{$\mathbf{N}$} & \multicolumn{2}{c}{ Mortalities } & \multicolumn{2}{c}{ Protected } \\
\cline { 3 - 6 } & & Number of fish & \% & Number of fish & \% \\
\hline G1 & 10 & 0 & 0 & 10 & 100 \\
\hline G2 & 10 & 4 & 40 & 6 & 60 \\
\hline G3 & 10 & 2 & 20 & 8 & 70 \\
\hline G5 & 10 & 3 & 30 & 7 & 80 \\
\hline
\end{tabular}

Means with different small litters in the same column at the same period are significantly different at $(\mathrm{p} \leq 0.05)$. 
The histopathological examination of group received Lead acetate only (control positive) showed slight pathological alteration where, Gills showed cellular hypeplasia and congestion, telangiectasis at the tips of secondary lamellae and extensive apoptosis i.e. the cells die and are sloughed (Photo: 2 A, B, C). Liver showed congestion in hepatic blood vessels and sinusoid, with necrotic changes and melanomacrophage infiltration (Photo: 3 A, B). Kidneys revealed degenerative changes in glomerular epithelium with inflammatory cells infiltration (Photo: 3C). The histopathological examination of $3^{\text {rd }}$ and $4^{\text {th }}$ groups revealed slight degenerative changes in the examined tissues. More-over best results were in the $5^{\text {th }}$ group that received Penicillium roqueforti and Tocopherol as gills only showed, mild congestion (Photo: 3D). Liver showed slight modulation as in (Photo: 4).
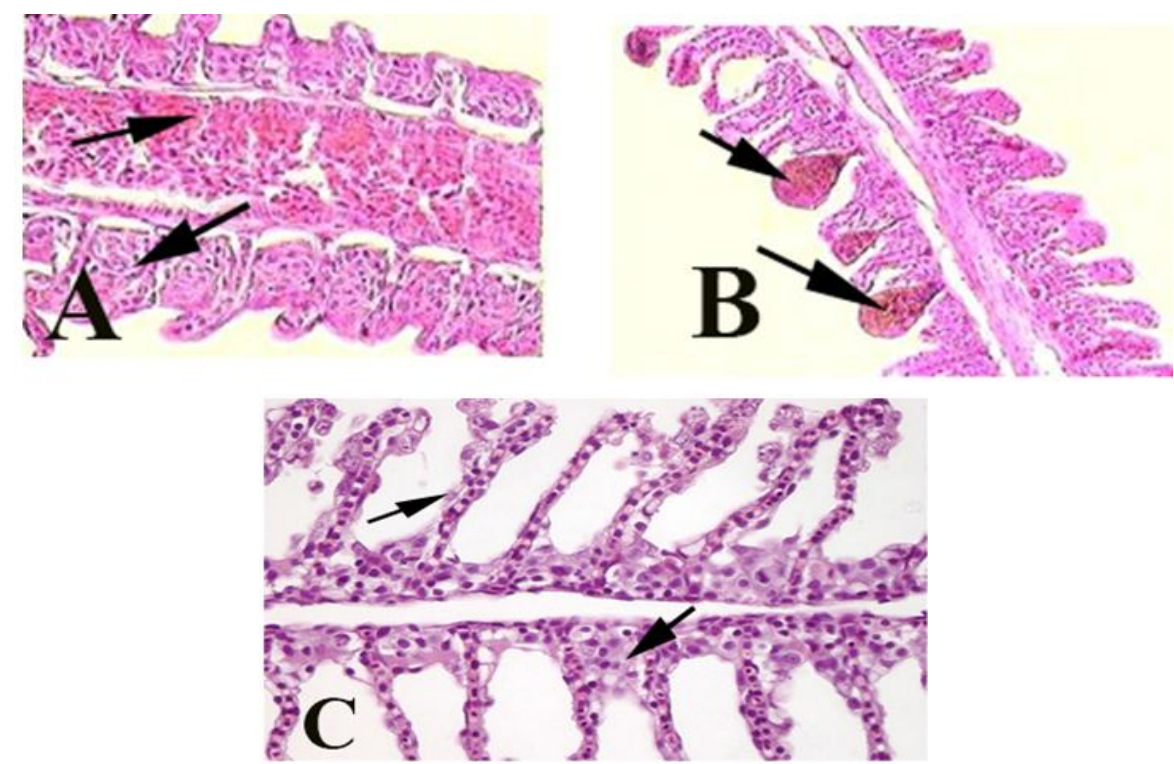

Photo 2: A- Gill of experimentally Lead intoxicated $O$. niloticus shows epithelial hyperplasia and blood congestion (arrows) (stain H\&E X 200).

B- Gill of experimentally Lead intoxicated $O$. niloticus shows telangiectasis at the tips of secondary lamellae (arrows) (stain H\&E X 200).

C- Gill of experimentally Lead intoxicated $O$. niloticus displaying extensive sloughing of epithelia linning (arrows) (H \&E X 200).
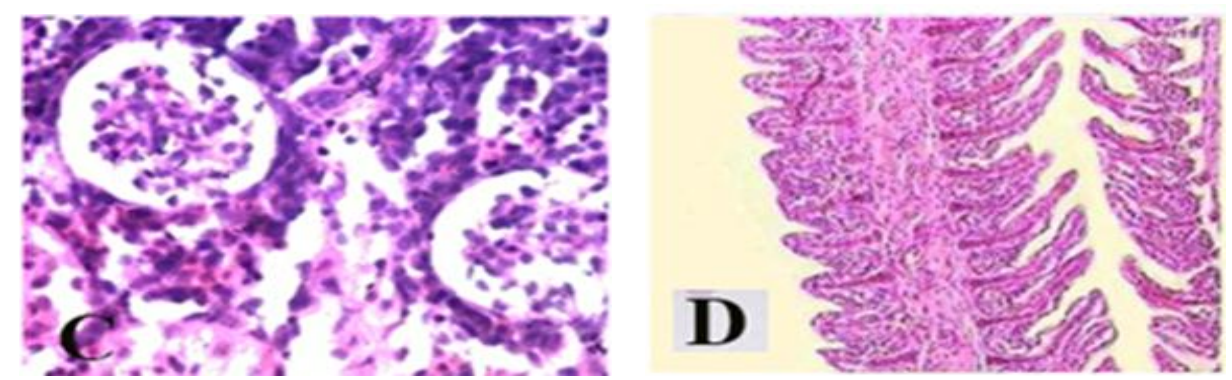

Photo 3: A- Liver of experimentally Lead intoxicated $O$. niloticus shows blood congestion (stain H\&E X 200).

B- Liver of experimentally Lead intoxicated $O$. niloticus shows melanomacrophages aggregate close to a bile duct (arrows) (stain H\&E X 200).

C- Kidney of experimentally Lead intoxicated $O$. niloticus shows degenerative changes in glomerular epithelium with inflammatory cells infiltration (H \&E X 200).

D- Gills of experimentally Lead intoxicated O. niloticus treated with Penicillium roqueforti and AlphaTocopherol shows slight hyperplasia and partial fusion of some lamellae (stain H\&E 200). 


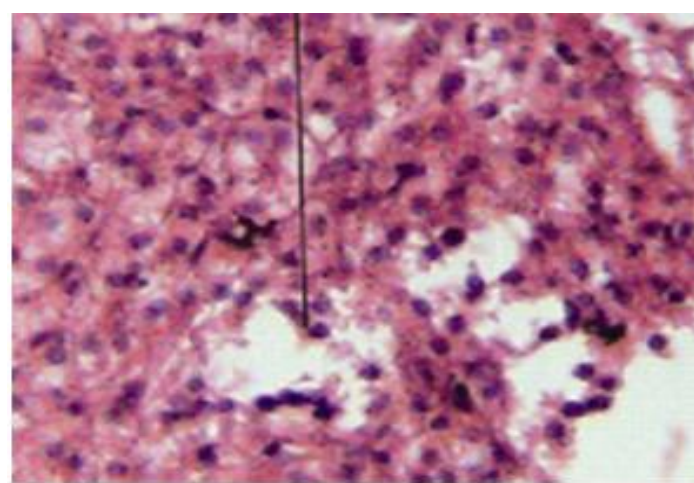

Photo 4: Liver of experimentally Lead intoxicated O. niloticus treated with Penicillium roqueforti and AlphaTocopherol shows minute focal areas of necrosis (stain H\&E X 200).

\section{DISCUSSION}

Heavy metals contamination of natural aquatic receptors and sediments is a major environmental problem (Srivastava and Thakur, 2006). Lead $\left(\mathrm{Pb}^{+2}\right)$ is one of heavy metals which found in the environment and causes several adverse effects. $\mathrm{Pb}^{+2}$ can change the physiological activities as well as causes histopathological changes of different organs in fish Marwa Salah et al. (2013).

Lead intoxicated fish groups $\left(2^{\text {nd }}, 3^{\text {rd }}, 4^{\text {th }}\right.$ and $\left.5^{\text {th }}\right)$ showed no characteristic symptoms externally comparing to the control negative (lead free) group and this is may be related to the cumulative and choronic nature of heavy metals adverse effects. Postmortem examination of $2^{\text {nd }}$ (control positive) group revealed the presence of edematous fluid, yellowish enlarged liver, enlarged gall bladder and spleen. Congestion of spleen, kidneys and gills was also recorded in comparing to control negative group. Regarding to $3^{\text {rd }}, 4^{\text {th }}, 5^{\text {th }}$ groups Postmortem examination revealed relatively enlarged pale liver, enlarged gall bladder and spleen comparing to the control negative group. These findings may be related to that gills, liver and kidneys are the main tissues of heavy metal $(\mathrm{Pb})$ uptake and accumulation (Gbem et al., 2001), Patnaik et al. (2011) and Luszczek-Trojnar et al. (2013). Moreover gill is an organ having a large surface as wellas separates fish blood from water and is very sensitive to changes in concentrations of heavy metals, temperature, $\mathrm{pH}$ and etc. in fish environment. For this reason gill tissue is a good indicators for water pollution (Koca et al., 2007). Liver plays a major role in the metabolism of lead; lead causes adverse effects to liver cells because liver is one of the major organs of lead storage, biotransformation as well as detoxification (Yomn and Mariam 2011). The observed Postmortem examination results $\left(2^{\text {nd }}\right.$ group) were confirmed by Histopathological picture in liver, gills and kidney which coordinate with results obtained in gills of experimentally lead acetate intoxicated Silver Sailfin Molly by (Yomn and Mariam 2011) in addition to Doaa and Hanan (2013) and Marwa Salah et al.
(2013) in the histological structure of gills and liver and in the histological structure of gills, liver and kidneys of o.niloticus experimentally intoxicated by lead acetate respectively. More-over nearly similar histopathological findings were reported by $\mathrm{Al}$ Balawi et al. (2013) in gills, liver and kidneys of Clarias gariepinus experimentally intoxicated by lead acetate and Sirimongkolvorakul et al. (2012) in gills and liver of experimentally intoxicated Puntius altus by Lead Nitrate $\left[\mathrm{Pb}\left(\mathrm{NO}_{3}\right)_{2}\right]$, respectively.

The analysis of growth hormone (GH) levels revealed significant reduction in $2^{\text {nd }}$ group (control positive) in comparing to other groups similar finding were observed by El-Shebly (2009) in lead (Pb) intoxication Oreochromis niloticus. Moreover this reduction increased by increasing the period of exposure to lead ( $8^{\text {th }}$ week) this may be related to the cumulative and choronic nature of heavy metals adverse effects. Best results of growth hormone levels were in $5^{\text {th }}$ group followed by $3^{\text {rd }}$ group followed by $4^{\text {th }}$ group then control negative (untreated) group respectively and this is may be related to the synergism between Penicillium roqueforti and alpha Alpha-Tocopherol as Several fungi are able to mineralize pollutant compounds by their non-specific highly oxidative ligninolytic enzymes (Bergsten et al., 2009). More-over Alpha-Tocopherol may act as useful tool for minimizing the lead toxic effects by its potent antioxidant activity El-Shebly (2009) in lead $(\mathrm{Pb})$ intoxicated Oreochromis niloticus (El-Shebly, 2002 and Apigail et al., 2003), recorded also, GH inhibition to heavy metals in the environmental samples.

The present study indicated significant reduction in calcium and phosphorus levels in all lead acetate treated O.niloticus groups in comparison to control negative group. These results are similar to those observed by Ajai et al. (2013) in the freshwater catfish, Heteropneustes fossilis. That was subjected to $164.4 \mathrm{mg} / \mathrm{L}\left(0.2\right.$ of $\left.96 \mathrm{~h} \mathrm{LC}_{50}\right)$ of lead nitrate for long-term experiment. Rogers et al. (2003) reported also hypocalcemia in lead-exposed rainbow trout. Generally divalent metals such as of zinc, lead and 
cadmium are considered calcium antagonists Kosai et al. (2011). The hypocalcemia observed in fish exposed to lead may be attributed to impairment of net electrolyte influx at the gill or impairment of renal function. Gills degeneration may affect the ionic permeability in addition to cause decreasing of the blood ionic levels. Tubular necrosis may be other possible cause for the observed hypocalcemia and hypophosphatemia (Ajai et al., 2013) they stated that, this may be also due to ionoregulatory toxicity induced by lead, particularly the $\mathrm{Ca}^{2+}$ homeostasis disturbance is not exclusively a branchial phenomenon, but is in part a result of ionoregulatory mechanisms disruption at the kidney. The observed results are confirmed by the gill and kidneys histopathological picture previously discussed.

Concerning effect of different treatments on lead residues of the examined samples of blood, gills tissues, liver, kidney and Muscular tissues of Oreochromis niloticus results revealed to that lowest lead residues were recorded in musculatures but the highest residues were recorded in gills These findings were similar to those obtained by (Al-Balawi et al. 2013) in Clarias gariepinus experimentally intoxicated by lead acetate. Moreover these results were in agreement with Bahnasawy et al. (2011) in their examination of the heavy metals in the water and fish in Lake Manzala they found that, the lowest lead residues concentrations were recorded in musculatures but the highest concentrations were in gills. Similar results were recorded by Y1lmaz, (2005) in fish muscles of grey mullet (Mugil cephalus) and Sea bream (Sparus aurata). Best results were recorded in the $5^{\text {th }}$ group followed by $3^{\text {rd }}$ then $4^{\text {th }}$ group. This is may be related to Penicillium roqueforti adsorption and mineralization to pollutant compounds through their non-specific highly oxidative ligninolytic enzymes (Bergsten et al., 2009) and its ability for removal of heavy metals from contaminated environments (Dugal and Gangawane 2012).

The non-specific immune parameters are considered useful tools for determining the fish health status and evaluation of the immunemodulatory substances for fish farming as pollution markers and diseases resistances (Sahoo et al., 2005). The present study revealed decreasing lysozyme activity as well as Bactericidal activity during the experimental period in control positive group ( $2^{\text {nd }}$ group) in compare with control negative group moreover this decreasing level increased in the $8^{\text {th }}$ week more than in $4^{\text {th }}$ week. These results were supported by El-Boshy and Taha (2011) in investigation of Mercuric chloride effect on the immunological parameters of Nile Tilapia. The best results were in $5^{\text {th }}$ group and this is may be related to the synergism between Penicillium roqueforti and Alpha-Tocopherol, where Alpha-Tocopherol has a very important role in immunity enhancement (John et al., 2001). In addition Penicillium roqueforti may act as probiotic so improve nonspecific immune response and so improve lysozyme activity as well as bactericidal activity this is may be supported by Taoka et al. (2006) who showed that viable probiotics supplemented to Japanese flounder (Paralichthys olivaceus), increased nonspecific immune response, that was determined by parameters as bactericidal activity, lysozyme activity and neutrophil migration, which improved fish resistance to infection.

Concerning mortalities of lead stressed O. niloticus challenged with Aeromonas hydrophila were significantly lower in all treated groups than the control positive group. These results supported by Omima Aboud (2010) in Oreochromis niloticus challenged with Ps. Fluorescence to evaluated lead, mercury and cadmium effects on both cellular and humeral immune response. Moreover low mortalities may attributed to the cumulative and chronic nature of lead toxicity and /or the lead acetate dose was sublethal dose similarly Pandey et al. (2000) concluded that dose- and dose-time-dependent increases the rate of mortality in response to mercuric toxicity in fish.

The best detoxifying results were achieved by the mixing Penicillium roqueforti with alpha-tocopherol. The observed detoxifying results may be related either to heavy metals removing ability of Penicillium roqueforti from contaminated environments (Dugal and Gangawane 2012) as Several fungi are able to mineralize pollutant compounds by their non- specific highly oxidative ligninolytic enzymes (Bergsten et $a l ., 2009$ ) and / or that vitamins ability to mobilize lead into the urine (Guluzar et al., 2006) as well as Alpha-Tocopherol provide protection against oxidative stress resulted from $\mathrm{Pb}$ toxicity (Seok et al., 2007 and El-Gaml et al., 2015).

\section{CONCLUSION}

Addition of Penicillium roqueforti plus AlphaTocopherol as feed supplements in O.niloticus diet in lead contaminated areas could have positive impacte on fish health by improving productivity (growth) through modulation of $\mathrm{GH}, \mathrm{Ca}$ and phosphorus. Moreover improving fish immunity and survivability by reducing the hazard effect of $\mathrm{Pb}$, it improve the external fish picture, growth and minimizing the $\mathrm{Pb}$ residues especially in fish musculatures.

\section{REFERENCES}

Ajai, K. Srivastav; Rubi, Rail; Nobuo, Suzuki; Diwakar, Mishra and Sunil, K. Srivastav (2013): Effects of lead on the plasma electrolytes of a freshwater fish, Heteropneustes fossilis. International aquatic research. J. http://www.intaquares.com/ content $/ 5 / 1 / 4$

Al-Balawi, H.F.A.; Al-Akel, A.S.; El Amin, F.A.; Suliman, M.; Al-Ghanim, Kh, A.; Mahboob, 
Sh. and Ahmad, Z. (2013): Effects of sublethal exposure of Lead Acetate on Histopathology of gills, liver, kidney and muscle and its accumulation in these organs of Clarias gariepinus. Brazilian archives of Biology and Technology.Vol.56, n.2: pp. 293302. March-April

AOAC (1984): Official methods for analysis of the association of Official Analytical Chemists. $14^{\text {th }}$ Edition, Arlington, Virginia, U.S.A. 1141.p.p.

APHA (1976): Standard methods for the examination of water and wastewater of the American Public Health Association. 14th Edition, Washington, DC, U.S.A. 1193 pp.

Apigail, M.; Brent, M.; William, A. and James, $N$. (2003): Heavy metal-induced inhibition of Aspergillus niger nitrate reductase: applications for rapid contaminant detection in aqueous samples. Analytical Chimica. Acta., 48(1): 131-142.

Ates, B.; Orun, I.; Talas, ZS.; Durmaz, G. and Yilmaz, I. (2008): Effects of sodium selenite on some biochemical and hematological parameters of rainbow trout (Oncorhynchus mykiss Walbaum, 1792) exposed to $\mathrm{Pb}^{2+}$ and $\mathrm{Cu}^{2+}$. Fish Physiol Biochem. 34:53-59.

Austin, B. and Austin, D.A. (1987): Bacterial fish pathogens: Diseases in Farmed and Wild fish. Ellis Harwood limited England, pp: 250-262.

Bahnasawy; Liao, W.R.; Lin, J.Y.; Shieh, W.Y. and Jeng, W.L. (2011): Antibiotic activity of lectins from marine algae against marine vibriosis. J. Ind. Microbial. Biotech. 30, 433439.

Bancroft, J.D.; Christopher, Layout and Suvarna, S.K. (2013): Bancroft's theory and practice of histological Techiques. $7^{\text {th }}$ ed Churchil Livingston Elsevier.

Bergsten-Torralba, L.R.; Nishikawa, M.M.; Baptista, D.F.; Magalhães, D.P. and Silva, M.I. da, IPrograma (2009): Decolorization of different textile dyes by Penicillium simplicissimum and toxicity evaluation after fungal treatment. Braz. J. Microbiol. vol.40 no.4 São Paulo Oct. Oct./Dec.

Doaa, M. Mokhtar and Hanan, H. Abd-Elhafeez (2013): Histological changes in selected organs of Oreochromis niloticus exposed to doses of Lead acetate. J. Life Sci. Biomed. 3(3): 256-263.

Dugal, S. and Gangawane, M. (2012): Metal tolerance and potential of penicillium species for use in mycoremediation. Journal of Chemical and Pharmaceutical Research, 4(5): 2362-2366.

El-Boshy, M.E. and Ramdan Taha (2011): Effects of Mercuric Chloride on the Immunological, Hematological, Biochemical Parameters and Diseases Resistance of Nile Tilapia
Challenged with Aeromnas hydrophila. Nature and Science; 9(12).

El-Gaml, A. Shimaa; Khalil, R.; Hashish, E.A. and El-Murr, A. (2015): Protective Effects of Selenium and Alpha-Tocopherol against LeadInduced Hepatic and Renal Toxicity in Oreochromis niloticus, J. Aquac Res. Development, 6:1.

El-Shebly, A.A. (2002): Effect of heavy metal pollution on growth hormone levels and growth rate of Oreochromis niloticus. Bull. Nat. Inst. Ocean ogr.\& Fish., A.R.E., 28: 191199.

El-Shebly, A.A. (2009): The role of antioxidant (Vitamin $\mathrm{E}$ ) in the control of Lead $(\mathrm{Pb})$ pollution and ehancement of growth within Nile Tilapia (Oreochromis niloticus). Intern. J. Appl. Res. Vet. Med. Vol. 7, No. 3.

Engstad, R.E.; Robertsen, B. and Frivold, E. (1992): Yeast glucan induces increase in lysozyme and complement-mediated haemolytic activity in Atlantic salmon blood. Fish and Shellfish Immunology. 2: 287 - 297.

Ezzouhril, L.; Castro, E.; Moya, M.; Espinola, F. and Lairinil, K. (2009): Heavy metal tolerance of filamentous fungi isolated from polluted sites in Tangier, Morocco. African Journal of Microbiology Research Vol. 3 (2) pp. 035-048.

Gavrilesca, M. (2004): Removal of heavy metals from the environment by biosorption. Eng. Life Sci. 4(3): 219-232.

Gbem, T.T.; Balogun, J.; Lawal, F.A. and Annune, P.A. (2001): Trace metal accumulation in Clarias gariepinus (Teugels) exposed to sublethal levels of tannery effluent. Sci. Total Environ. 271: 1-9.

Guluzer, A.; Özlem, A.; Seyhan, T. and Mustafa, C. (2006): Response of catalase activity to $\mathrm{Ag}^{+}, \mathrm{Cd}^{2+}, \mathrm{Cr}^{6+}, \mathrm{Cu}^{2+}$ and $\mathrm{Zn}^{2+}$ in five tissues of freshwater fish (Oreochromis niloticus): Comparative Biochemistry and Physiology Part C: Toxicology\& Pharmacology, 143(2): $218-224$.

Gupta, R.; Ahuja, P.; Khan, S.; Saxena, R.K. and Mohapatra, H. (2000): Microbial biosorbents: Meeting challenges of heavy metal pollution in aqueous solutions. Curr. Sci. 78(8): 967973.

Hawak, P.P.; Oscar, B.L. and Summerson, W. (1965): Hawak's physiological, Chemistry. London J., and. Churchill Ltd. 14th Ed. HEA Ireland (2002-2005).

Innes, W.T. (1966): Exotic aquarium fishes. $19^{\text {th }}$ Ed. Aquarium in Corported, New Jersy, USA.

John, S.; Kale, M.; Rathore, N. and Bhatnagar, D. (2001): Protective effect of vitamin E in dimethoate and malathion induced oxidative stress in rat erythrocytes. J. Nutr. Biochem. 12: 500-504. 
Jonsson, S.; Skyllberg, U.; Nilsson, M.B.; Westlund, P.O.; Shchukarev, A.; Lundberg, E. and Björn, E. (2012): Mercury methylation rates for geochemically relevant $\mathrm{Hg}$ (II) species in sediments. Environ Sci Technol. 2012 Nov 6; 46(21):11653-9. doi: 10.1021/es3015327. Epub 2012 Oct 25.

Kates, S.A. and Albericio, A. (2000): Solid-phase Synthesis: A Practical Guide. New York, NY: Marcel Dekker; 2000.

Koca, S.; Koca, YB.; Yildiz, S. and Gurcu, B. (2007): Genotoxic and histopathological effects of water pollution on two fish species, Barbus capito pectoralis and Chondrostoma nasus in the Buyuk Menderes. Biol Trace Elem Res. 122: 276-291.

Kosai, P.; Jiraungkoorskul, W.; Synsatayakul, A. and Jiraungkoorskul, K. (2011): Efficacy of calcium reducing lead toxicity in hematology of Oreochromis niloticus. J. of Fisheries and Aquatic Science, 6 (3): 346-355.

Lied, E.; Gezerde, Z. and Braskhan, D.R. (1975): Simple and rapid technique for repeated blood sampling in Rainbow trout. J. of Fish Res. Board of Canada, 32(5): 699-701.

Linde, AR.; Sanchez-Galan, S. and Garcia-Vazques, E. (2004): Heavy metal contamination of European eel (Anguilla anguilla) and brown trout (Salmo trutta) caught in wild ecosystems in Spain. J Food Prot. 67:2332-2336

Luszczek-Trojnar, E.; Drag-Kozak, E. and Popek, W. (2013): Lead accumulation and elimination in tissues of Prussian carp, Carassius gibelio, after long-term dietary exposure, and depuration periods. Environ Sci Pollut Res Int 20: 3122-3132.

Marwa, Salah; Ahmed, Farghali, A.A.; Hasnaa, Azmy and Mohamed Khedr, M.H. (2013): Biological compatibility of carbon nanotubes for treatment of Pollution of Nile tilapia (Oreochromis niloticus) by lead acetate. Life Science Journal, 10 (2).

Mason, C. (1991): Biology of freshwater pollution. Longman Scientific and Technical, Harlow, England.

Montero, D.; Tort, L.; Robaina, L.; Vergara, JM. and Izquierdo, MS. (2001): Low reduces stress resistance of gilthead seabream (Sparus aurata) juveniles. Fish Shellfish Immunol 11: 473-490.

Nakane, P.K. and Kawaoi, A. (1974): Peroxidaselabeled antibody. A new method of conjugation. J. Histochem. Cytochem. 1974; 22 (12): 1084-1091.

Olaifa, F.E.; Olaifa, A.K. and Lewis, O.O. (2003): Toxic stress of Lead on Clarias gariepinus (African catfish) fingerlings. African Journal of Biomedical Research, Vol. 6; $101-104$.

Omima, A.S.A. Aboud (2010): Impact of pollution with lead, mercury and cadmium on the immune response of Oreochromis niloticus. J. New York Science, 3(9): 12 - 16.

Patnaik, B.B.; Howrelia, H.J.; Mathews, T. and Selvanayagam, M. (2011): Histopathology of gill, liver, muscle and brain of Cyprinus carpio communis L.exposed to sublethal concentration of lead and cadmium. Afr .J. of Biotechnol., 10 (57): 11118-12223.

Pandey, A.; Nigam, P.; Soccol, C.R.; Soccol, V.T.; Singh, D. and Mohan R. (2000): Advances in microbial amylases (review article), Biotechnol. Appl. Biochem. 31135-152.

Plumb, J.A. and Bowser, P.R. (1982): A laboratory manual of microbial fish diseases. Auburn Univ., Auburn, Alabama, pp: 77.

Puangkaew, J.; Kiron, V.; Somamoto, T.; Okamoto, N.; Satoh, S.; Takeuchi, T. and Watanabe, T. (2004): Nonspecific immune esponse of rainbow trout (Oncorhynchus mykiss Walbaum) in relation to different status of vitamin $\mathrm{E}$ and highly unsaturated fatty acids. Fish Shellfish Immunol. 16:25-39.

Rainger, G.E. and Rowley, A.F. (1993): Antibacterial activity in the serum and mucus of rainbow trout, Oncorhynchus mykiss, following immunization with Aeromonas salmonicida. Fish and shellfish Immunology, 3. 475-482.

Rogers, J.T.; Richards, J.G. and Wood, CM. (2003): Ionoregulatory disruption as the acute toxic mechanism for lead in the rainbow trout (Oncorhynchus mykiss). Aquat Toxicol 16: 215-234.

S.P.S.S. (1997): Statistical package for the social sciences, Revisions 6, spss Inc, Chicago, USA.

Sahoo, P.K.; Kumari, J. and Mishra, B.K. (2005): Non-specific immune responses in juveniles of Indian major carps. Journal of AppliedIchthyology; 21(20):151-55.

Seok, SH.; Baek, MW.; Lee, HY.; Kim, DJ.; Na, YR.; Noh, KJ.; Park, SH.; Lee, HK.; Lee, BH.; Ryu, DY. and Park, JH. (2007): Arsenite-induced apoptosis is prevented by antioxidants in zebra fish liver cell line. Toxicology inVitro, 21(5): 870-877.

Sidra, Riaz and Sumera, Sajjad (2012): Effect of Lead toxicity on Growth Hormone levels in fish (Lead Toxicity in Fish). Book Published by LAP Lambert Academic Publishing.

Soliman, M.K. (1988): Studies on Aeromonas hydrophila on some cultured freshwater fish "Oreochromis niloticus ". Ph.D. Thesis, Avian and Aquatic Anima. Med., Fac. Of Vet. Med. Alex. Univ.

Srivastava, S. and Thakur, I.S. (2006): Biosorption potency of Aspergillus niger for removal of chromium (VI). Curr. Microbiol. 53: 232-237.

Sirimongkolvorakul, $\quad$ S.; $\quad$ Tansatit, $\quad T$.; Preyavichyapugdee, N.; Kosai, $\quad$ P.; Jiraungkoorsku, K. and Jiraungkoorskul, W. (2012): Efficiency of Moringa oleifera dietary supplement reducing lead toxicity in Puntius 
altus. Medicinal Plants Research J. Vol. 6(2), pp. 187-194, 16 January.

Stephen, T.E.; Lewis, S.D.H. and Grumbles, L.C. (2000): Comparison of selected diagostic tests for detection of motile Aeromonas septicaemia in fish. Am. J. Vol. Res., 39 (8): 1384-1386.

Storelli, M.; Giacominelli-Stuffler, $R$. and Marcotrigiano, G. (2002): Mercury accumulation and speciation in muscle tissue of different species of sharks from Mediterranean Sea, Italy. Bull. Environ. Contam. Toxicol. (68): $201-210$.

Taoka, Y.; H. Maeda, J. and Y.Jo. (2006): Growth, stress tolerance and non-specific immune response of Japanese flounder (Paralichthys olivaceus) to probiotics in a closed recirculating system. Fisheries Science, Vol. 72, No.2, pp. 310-321.

Uluozlu, O.D.; Tuzen, M.; Mendil, D. and Soylak, M. (2007): Trace metal content in nine species of fish from the Black and Aegean Seas, Turkey. Food Chemistry, (104): 835 - 840.

Yllmaz, A.B. (2005): Comparison of heavy metal levels of grey mullet (Mugil cephalus) and Sea bream (Sparus aurata) caught in İskenderun Bay (Turkey). Turk. J. Vet. Anim. Sci., (29): $257-262$.

Yomn, M.S. Mobarak and Mariam, M. Sharaf (2011): Lead acetate-induced histopathological changes in gills and digestive system of Silver Sailfin Molly (Poecilia latipinna).International J. of Zoological Research, 7 (1):1-18.

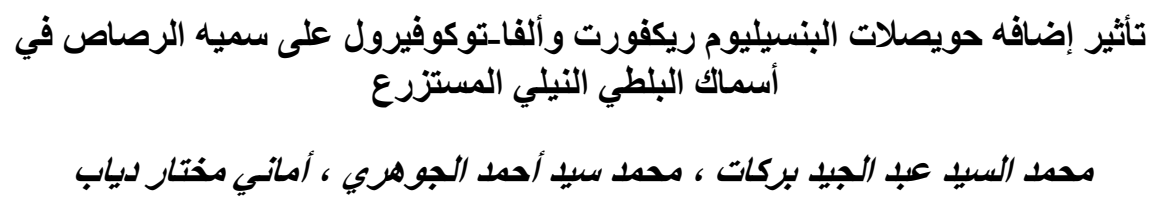

Email: mmbarakat2003@gmail.com Assiut University web-site: www.aun.edu.eg

صممت هذه التجربه لار اسة التأثثر السام لجر عه الرصاص (خلات الرصاص) الغير مميته على أسماك البلطي النيلي وكذللك تأثير

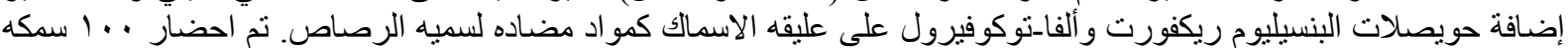

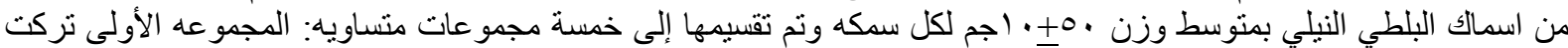

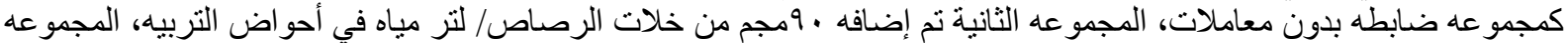

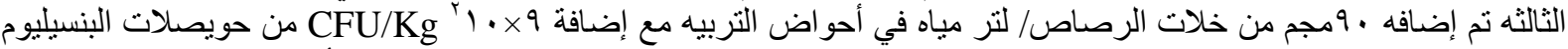

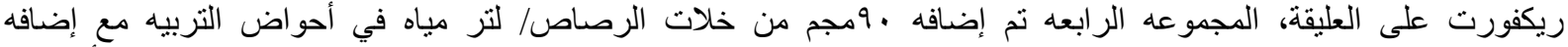

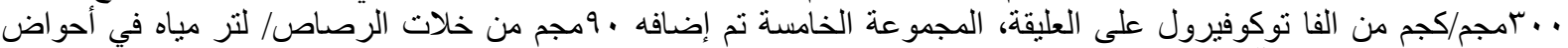

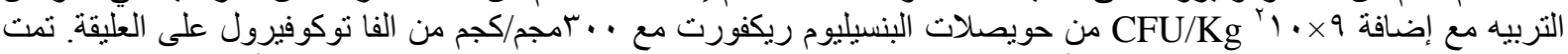

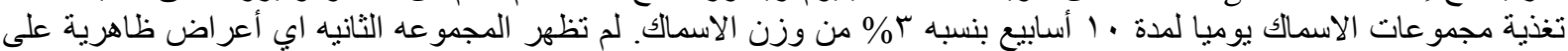

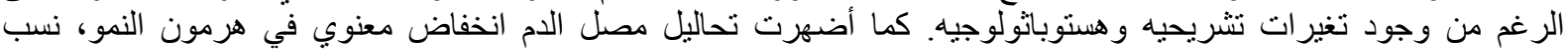

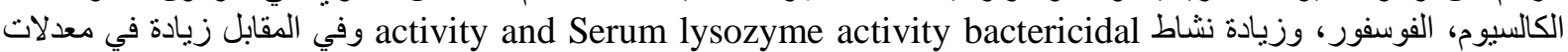

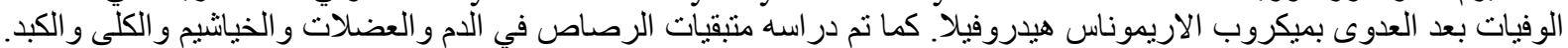

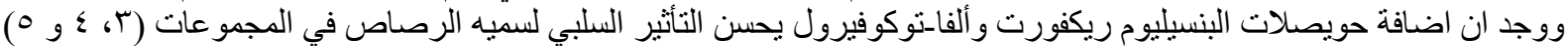

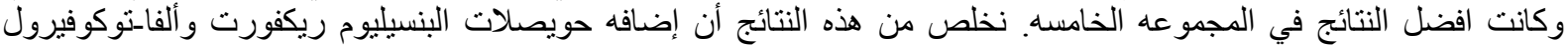
لعلائق الاسماك يقلل من التأثثر السام للرصاص كما انه يقلل من الأثر التر اكمي للرصاص فن وخصوصا في عضلات الاسماك. 